\title{
BIOMASS AND PRODUCTIVITY OF WEEDS IN A FALLOW PERIOD AT GUJAR TAL MARGIN, INDIA
}

\author{
Mayank Singh, O.P. Singh 'Vatsa' and M.P. Singh* \\ Department of Botany \\ T.D.College, Jaunpur-222002, U.P., India \\ *E-mail: mahendrapratapsingh@gmail.com
}

\begin{abstract}
This paper deals with biomass accumulation and net primary productivity pattern in a fallow period of a lake margin agroecosystem. The slight slopping margin of present study site was characterized into two ecological zones, i.e. upper and lower from top up-land to lower region near water margin. Maximum biomass of dominant weed Cynodon dactylon (Linn) Pers. and 'rest (other) weeds' were 190.55 and $265.22 \mathrm{~g} \mathrm{~m}^{-2}$ in upper zone in September. In contrast, in the lower zone of study site, peak value of biomass of dominant plant $C$. dactylon and 'rest weeds' were 67.91 and $178.84 \mathrm{~g} \mathrm{~m}^{-2}$, respectively in June as lower zone was inundated from first fortnight of July to September, 2008. Maximum percentage contribution of the weed (C. dactylon) was 54.00 and $59.15 \%$ in March and 'rest weeds' was 74.49 and 75.15\% in April, 2008 in the respective upper and lower zones. Maximum productivity values of respective dominant weed (C. dactylon) and 'rest weeds' in upper zone were 2.07 and $2.51 \mathrm{~g} \mathrm{~m}^{-2}$ day $^{-1}$ in July. In contrast, in the lower zone of the study site peak productivity values of respective dominant weed ( $C$. dactylon) and 'rest weeds' were observed 1.36 in June and $1.23 \mathrm{~g} \mathrm{~m}^{-2}$ day $^{-1}$ in October. Total productivity values in two respective zones upper and lower zones varied between 330.59 and $140.17 \mathrm{~g} \mathrm{~m}^{-2}$ per eight month. Analysis of variance in standing biomass of plant species was found significant $\mathrm{p}<0.05$ in upper zone and $\mathrm{p}<0.01$ in lower zone.
\end{abstract}

Key words: Biomass, productivity, fallow land, weed, lake margin.

\section{INTRODUCTION}

Lake margins usually with slopping topography are complex assemblage of organisms and their environment existing adjacent to lake water. The amplitude of water level fluctuations in the lake, duration of inundation of lake margin and agricultural operations mainly for winter cropping are the main controlling factor of occurrence of plant species composition, structure, biomass and productivity during fallow period in such ecotone. The soil of these habitats faces two extremes, i.e., inundation during rainy season and extreme dry condition in summer, besides other biotic forces.
One fundamental dimension of an ecosystem is its productivity- the rate of creation of organic material by photosynthesis (Whittaker 1970). The structural parameter, biomass and functional parameter, production, both essential in the process of ecosystem analysis are of importance (Reichle 1975). Global net primary productivity is approximately $120 \times 10^{9} \mathrm{t}$ dry weight on land (Mackenzie et al. 2002). Jain and Vayas (1980) have studied the dry matter transfer relationships in dry bank community of Gordhan Vilas lake (Udaipur) dominated by Cynodon dactylon. Singh and Ambasht (1990), Kapoor and Singh (2007) 
and Sinha and Singh (2010) have studied biomass and productivity in different ecosystems but still there has been scarcity of data on such habitat. Therefore, present investigation has been carried out to understand the ecological attributes of biomass accumulation and net primary productivity pattern in such fallowland near a tropical lake.

\section{MATERIALS AND METHODS}

Study site: This study was carried out near 'Gujar Tal' (24 ${ }^{\circ} 6^{\prime}-25^{\circ} 5^{\prime} \mathrm{N}$ and $80-82^{\circ} \mathrm{E}$ longitude) in the north western region of Jaunpur (U.P.) $28 \mathrm{~km}$ from the city and $1.5 \mathrm{~km}$ to the west of Khetasarai market. The present study site $(50 \times 200 \mathrm{~m})$ was divided into two zones, i.e. upper $\left(10-15^{\circ}\right)$ and lower $\left(5-10^{\circ}\right)$. These zones differed in respect to degree of slope, number of days of inundation, soil moisture content and soil texture, etc. The lower zone was fully inundated after first fortnight of July to September, 2008. The cultivation of crops on these slopes is usually done for four months only during winter season due to extremely dry condition in summer and sudden rise of water level during rainy season. The study site was left as fallow land for the remaining eight months. The soil $\mathrm{pH}$ of the study site varied from 7 to 8 .

The climate is typically mansoonic with three different seasons viz. summer, rainy and winter. Total rainfall during study (April 2008 to March 2009) was $1346.8 \mathrm{~mm}$ out of which about 1295.4 $\mathrm{mm}$ was during rainy season.

Sampling method and calculation: On the basis of Importance Value Index (IVI) Cynodon dactylon was the most dominant weed (MullerDombois and Ellenberg 1974, Singh and Ambasht 1990). C. dactylon was studied separately and the remaining weeds were put together as 'rest weeds'. Short term harvest method (Odum 1960) was followed to determine the biomass and dry matter production. In order to get the shoots and roots intact of different species of the community, the core technique, as recommended by Dahlman and Kucera (1965) and Lieth and Whittaker (1975) have been followed in the present investigation.
Sampling was done fortnightly by excavating monoliths in triplicate on $25 \mathrm{~cm} \times 25 \mathrm{~cm}$ area up to a depth of $30 \mathrm{~cm}$ (Goodall 1952 and Golley 1965) from two different zones. Underground parts of some plants penetrate deeper than $30 \mathrm{~cm}$, but more than 95 percent of underground biomass was found to be concentrated in top $30 \mathrm{~cm}$ depth only. The harvested plant material was washed gently with water in wire-cage avoiding root breaking as far as possible. The plant parts are divided component wise, into aboveground (AG) and underground (UG) parts. Rhizomes of the plant were included into underground part. Samples were dried at $80^{\circ} \mathrm{C}$ for $48 \mathrm{~h}$ in oven and weighed to find out the value for biomass. Analysis of variance was applied to the total biomass community and standard error has also been calculated (Campbell 1974). The net gain in biomass between periods of time over a unit land area is its net productivity. Therefore, the productivity of aboveground (AG) and underground (UG) parts of the dominant weed $(C$. dactylon), 'rest weeds' and entire community have been calculated separately. Sum of positive differences in the biomass values were used to calculate production for the period of eight months (Singh and Yadava 1974).

\section{RESULTS AND DISCUSSION}

Maximum biomass of dominant weed $(C$. dactylon) for aboveground and underground parts was 121.84 and $68.71 \mathrm{~g} \mathrm{~m}^{-2}$, respectively at study site in the month of September (Fig. 1). In contrast, its peak biomass values in the lower zone for the respective aboveground and underground parts were 40.79 and $27.12 \mathrm{~g} \mathrm{~m}^{-2}$ in June as this zone was later inundated or flooded with water. Similarly the peak biomass for 'rest weeds' of aboveground and underground parts were recorded as 167.80 and $97.42 \mathrm{~g} \mathrm{~m}^{-2}$ in the month of September in upper zone, and 78.32 and $32.61 \mathrm{~g} \mathrm{~m}^{-}$ 2 in the lower zone, respectively. Maximum biomass of total community was 455.77 (September) and $178.84 \mathrm{~g} \mathrm{~m}^{-2}$ (June) in two respective zones, i.e. upper and lower (Fig. 1). 

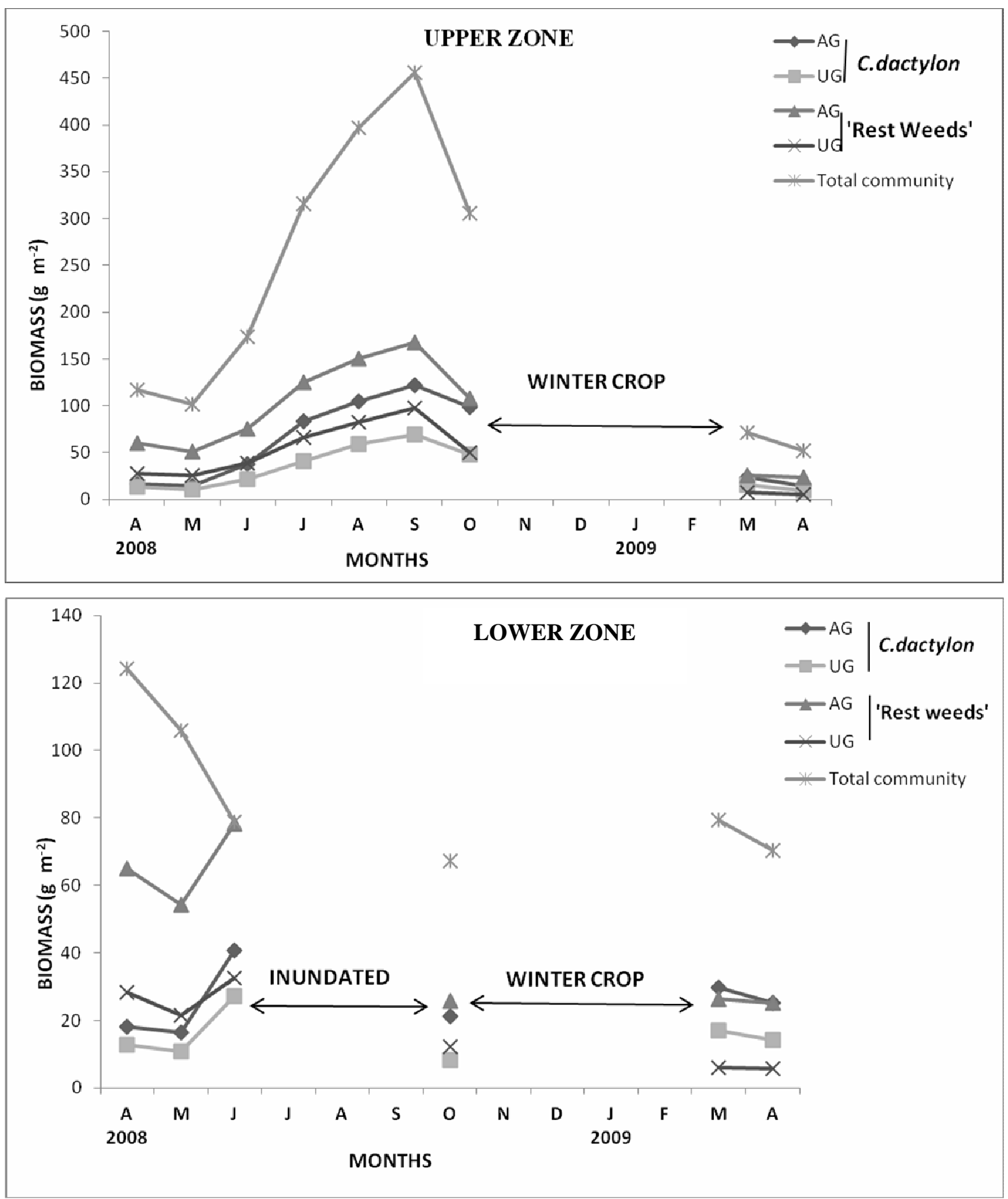

Fig. 1. Monthly variation in standing biomass $\left(\mathrm{g} \mathrm{m}^{-2}\right)$ of different components of dominant weed (C. dactylon), 'rest (other) weeds' and total community at study site, during fallow period, in two different zones.

In the present study, throughout the fallow period biomass varied significantly in the two ECOPRINT VOL 18, 2011 zones due to variety of interacting forces. Higher temperature, hot winds and low percentage of soil 
moisture content prevailing during summer season retarded the growth of plant species. But with the advent of rain in the rainy season annuals, legumes and grasses have grown rapidly. In the study stand plant biomass was maximum during rainy season when there was sufficient soil moisture and humidity in the atmosphere. The increased biomass during rainy season is mainly due to increase in number of plants. Similar findings have been reported by Singh (1967) for grasslands. Zone wise visualization of the study stand depicted that before flooding in the month of June, maximum community biomass at site was $178.84 \mathrm{~g} \mathrm{~m}^{-2}$ in the lower zone followed by upper zone $\left(173.35 \mathrm{~g} \mathrm{~m}^{-2}\right)$. Beyond September, the values of standing crop biomass declined gradually in the upper zone, firstly due to depletion of soil moisture as particular zone has escaped inundation. Secondly, it was the result of normal decline followed by maturity (Singh and Ambasht 1990). Lastly, seed and leaf fall, biotic forces viz., removal of vegetation by intensive grazing, herbivory by insects, rodents, etc. have also lowered biomass during dry period. In contrast, inundation of the lower zone has lowered biomass after the exposure, all the plants were dead due to floodwater in October in the lower zone most of the winter annuals appeared everywhere showing staggered germination. In the present study, major community biomass is shared by 'rest weeds' throughout the study period except in March 2009 after harvesting of the winter crop in the upper and lower zones. It is mainly due to selective grazing and scraping of palatable grass $C$. dactylon which might have resulted its lower biomass (Fig. 1). The percentage contribution of 'rest weeds' was high in comparison to dominant weed $C$. dactylon, except in March in both the zones and in April 2009 in the lower zone (Fig. 2).

66
The significance of variations at different sites in biomass in relation to plant species was tested by analysis of variance. Variations due to plant species were found significant $(p<0.05$ in upper zone and $\mathrm{p}<0.01$ in the lower zone) (Table 1 ).

Table 1. ANOVA for biomass $\left(\mathrm{g} \mathrm{m}^{-2}\right)$ variation between plant species across the months at study site, during fallow period, in two different zones

\begin{tabular}{lcccc}
\hline Source & S.S. & d.f. & M.S. & F \\
\hline Upper zone & & & & \\
Plant species & 23796.92 & 1 & 11898.46 & $1.36^{\text {ns }}$ \\
Months & 62906.24 & 7 & 31453.12 & $3.60^{*}$ \\
Error & 41.80 & 8 & & \\
Total & 86744.96 & 16 & & \\
Lower zone & & & & \\
Plant species & 3302.23 & 1 & 1651.12 & $0.95^{\text {ns }}$ \\
Months & 49548.50 & 7 & 24774.25 & $14.32^{*}$ \\
Error & 45.44 & 8 & & \\
Total & 52896.17 & 16 & & \\
\hline
\end{tabular}

$\mathrm{ns}=$ Not significant, significant at $\mathrm{p}<0.01$, significant at $\mathrm{p}<0.05$.

The trend of net primary productivity was negative during summer season. It is mainly because the fresh growth was negligible as compared to loss in the form of litter. The first monsoon shower in the middle of June has accelerated rate of production in the study stand. Maximum net primary productivity (Fig. 3) of dominant plant ( $C$. dactylon) for aboveground and underground parts was 1.45 and $0.62 \mathrm{~g} \mathrm{~m}^{-2}$ day $^{-1}$ in July. In contrast, its peak productivity value in the lower zone for respective aboveground and underground parts were 0.82 and $0.54 \mathrm{~g} \mathrm{~m}^{-2}$ day $^{-1}$ in the month of June as this zone has faced inundation. Similarly, maximum net primary productivity values of 'rest weeds' for aboveground and underground parts were recorded 1.61 and $0.89 \mathrm{~g} \mathrm{~m}^{-2}$ day $^{-1}$ in July in upper zone and 0.83 and $0.40 \mathrm{~g} \mathrm{~m}^{-2}$ day $^{-1}$ after exposure of flooded water in October in the lower zone, respectively.

ECOPRINT VOL 18, 2011 

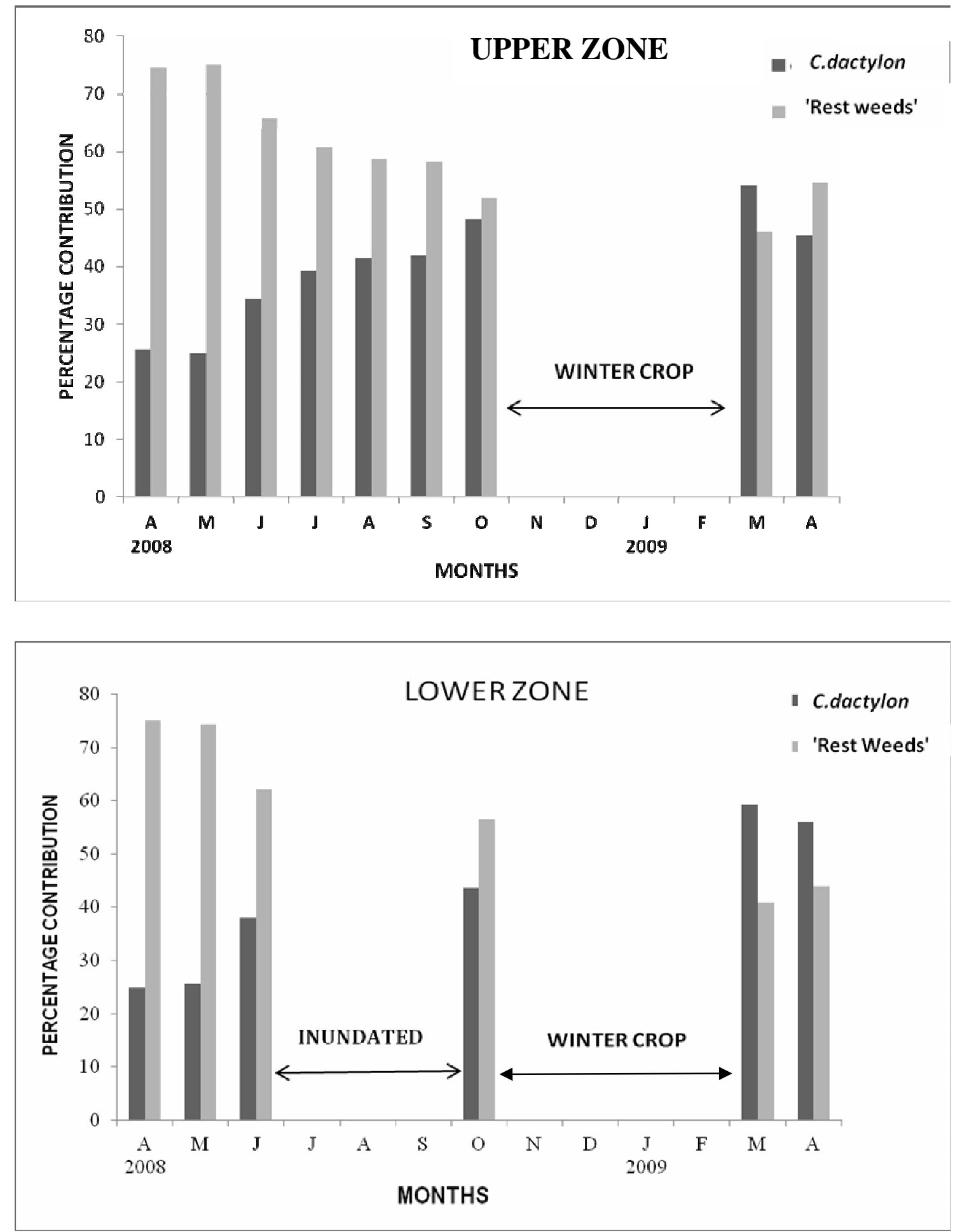

Fig. 2. Monthly variation in percentage contribution of dominant weed $(C$. dactylon) and 'Rest (other) weeds' in two different zones at study site during fallow period. 

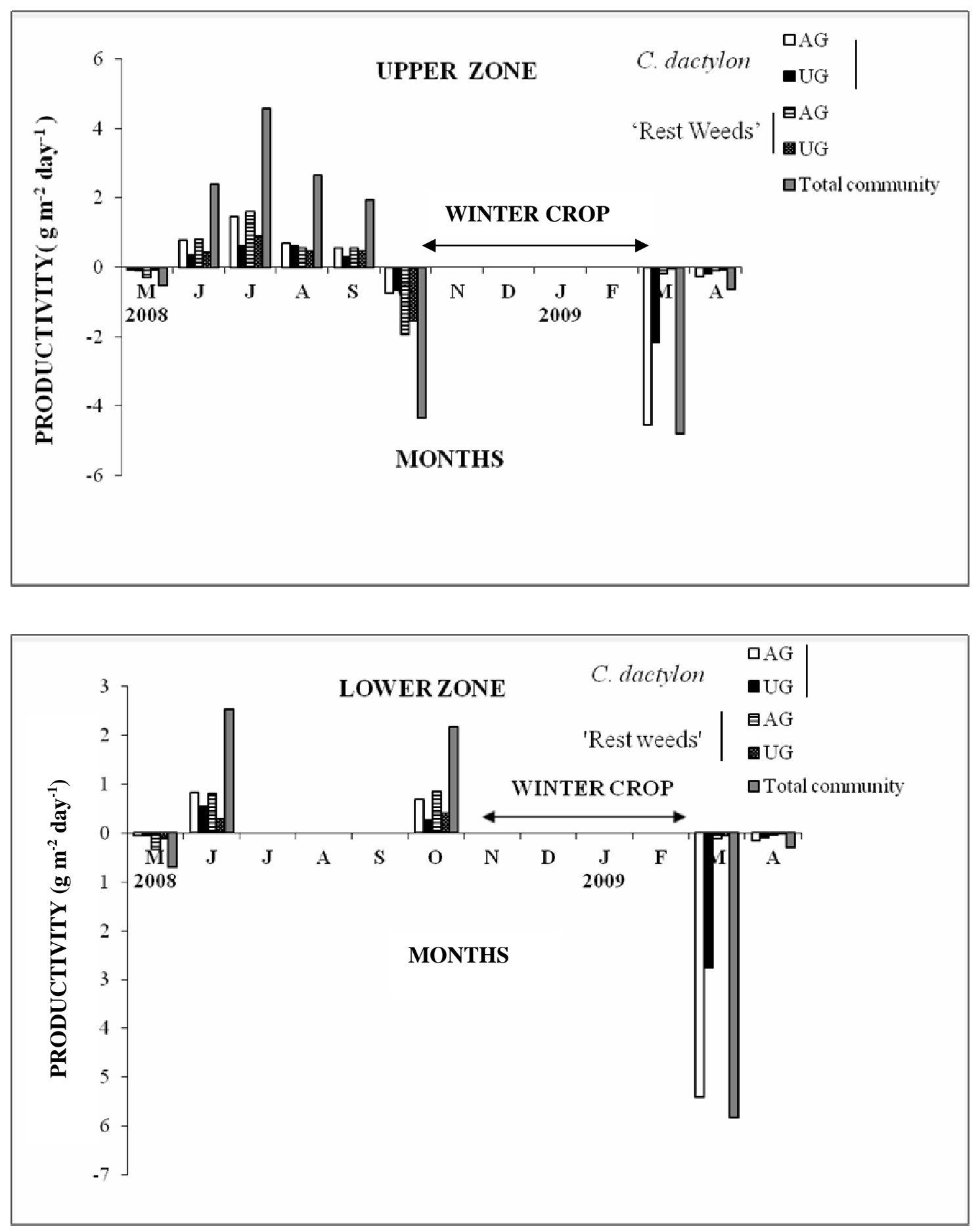

Fig. 3. Monthly variation in net productivity $\left(\mathrm{g} \mathrm{m}^{-2}\right.$ day $\left.^{-1}\right)$ of different components of dominant weed (C. dactylon), 'Rest (other) weeds' and total community at study site during fallow period in two different zones ( $\mathrm{AG}=$ Aboveground, $\mathbf{U G}=$ Underground $)$. 
Table 2. Monthly variation in total net production $\left(\mathrm{g} \mathrm{m}^{-2}\right)$ of dominant weed (Cynodon dactylon), 'rest weeds' and total community at the study site during fallow period in two different zones.

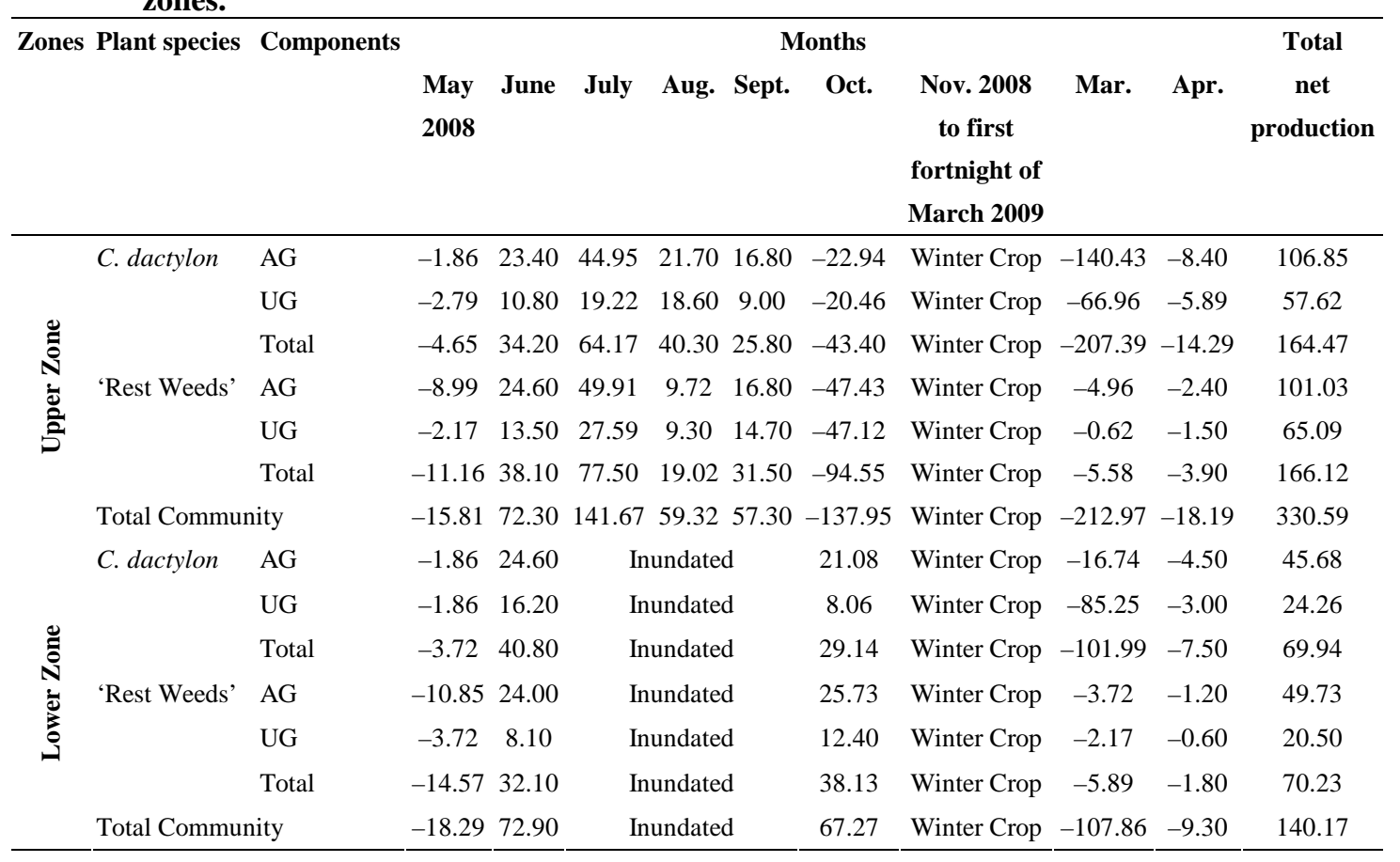

However, after recession of the flood-water in October, lower zone has shown positive trend of productivity that might be due to fresh growth of the weeds. It is mainly due to better soil moisture and nutrients in comparison to upper zone (Fig. 3).

Total maximum net production of dominant weed (C. dactylon) was 164.47 and $69.94 \mathrm{~g} \mathrm{~m}^{-2}$ for eight months in the upper zone and lower zone respectively (Table 2). In contrast, the value of 'rest weeds' was slightly high and $70.23 \mathrm{~g} \mathrm{~m}^{-2}$ per eight months in the respective two zones. Productivity value for entire community during fallow period at study site was maximum in upper zone $\left(33.59 \mathrm{~g} \mathrm{~m}^{-2}\right.$ for eight month) followed by lower zone (140.17 $\mathrm{g} \mathrm{m}^{-2}$ for eight month). It clearly indicates that in spite of better soil moisture (Singh et al. 2010) and nutrients status in the lower zone, it had shown lower value of productivity of entire community due to impact of longer period of inundation in comparison to upper zone.

\section{ACKNOWLEDGEMENTS}

Authors are thankful to the Principal, T.D. College, Jaunpur for providing laboratory facilities during the study period and Dr. U.K. Singh (Retd. Reader and Head of Botany) for his help and encouragement.

\section{REFERENCES}

Campbell, R.C. 1974. Stastistics for Biologists. Cambridge University Press, London.

Dahlman, R.C. and C.L. Kucera. 1965. Root productivity and turnover in a native praire. Ecology 46:84-89.

Golley, F.B. 1965. Structure and function of old field broom sedge community. Ecol. Monogr. 35:113-131.

Goodall, D.W. 1952. Quantitative aspects of plant distribution. Biol. Rev. 27:195-245. 
Jain, S.L. and L.N. Vayas. 1980. Dry matter transfer relationship in dry bank community, Gobardhan Vilas Lake, Udaipur, Inst. Indian Conf. Ecol. Environmental Sci. Jaipur. Abstract 32 pp.

Kapoor, S. and M.P. Singh. 2007. Biomass and primary production of railway track embankment vegetation. Indian Journal of Ecological Society 34:28-30.

Lieth, H. and R.H. Whittaker. 1975. Primary Productivity of Biosphere. Ecological studies in Springer Verlag. New York.

Mackenzie, A., A.S. Ball and S.R. Virdee. 2002. Instant Notes on Ecology. Viva Books Private Limited, New Delhi. Section P-Ecosystem processes, $180 \mathrm{pp}$.

Muller-Dombios, D. and H. Ellenberg. 1974. Aims and Methods of Vegetation Ecology. John Wiley and Sons, New York.

Odum, E.P. 1960. Organic production and turn over in old field succession. Ecology 41:3449.

Reichle, D.E. 1975. Advances in ecosystem analysis. Bioscience 25:257-264.
Singh, J.S. 1967. Seasonal Variation in Composition, Plant Biomass and Net Community Production in Grassland at Varanasi. Ph.D. Thesis, Department of Botany, B.H.U.,Varanasi, India.

Singh, M.P. and R.S. Ambasht. 1990. Impact of flooding on the biomass and productivity pattern in a fallow land of Gomati riparian agro ecosystem. J. Env. Sci. 3(1):25-36.

Singh, J.S. and P.S. Yadav.1974. Seasonal variation in composition, plant biomass and net primary productivity of tropical grassland Kurukshetra. Ecol. Mono. 44:357-376.

Singh, M., O.P.Singh 'Vatsa' and M.P. Singh. 2010. Changes in physical characteristics of soil of Gujar Lake ecotone soils in different seasons. Jour. P.A.S. 16:72-82.

Sinha, S. and M.P. Singh. 2010. Biomass and primary productivity of a neglected wasteland at Jaunpur (U.P.), India. Plant Archieves 10(2):719-723.

Whittaker, R.H. 1970. Communities and Ecosystem. The Macmillan Company, New York, $162 \mathrm{pp}$. 